Review

\title{
Voltage-Gated Calcium Channel Antagonists and Traumatic Brain Injury
}

\section{Gene Gurkoff ${ }^{1,2}$,*, Kiarash Shahlaie ${ }^{1}$, Bruce Lyeth ${ }^{1}$ and Robert Berman ${ }^{1}$}

1 Department of Neurological Surgery, One Shields Avenue, University of California, Davis, CA 95616, USA; E-Mails: kiarash_shahlaie@ucdmc.ucdavis.edu (K.S.); bglyeth@ucdavis.edu (B.L.); rfberman@ucdavis.edu (R.B.)

2 NSF Center for Biophotonics Science and Technology, Suite 2700 Stockton Blvd, Suite 1400, Sacramento, CA, 95817, USA

* Author to whom correspondence should be addressed; E-Mail: gggurkoff@ucdavis.edu; Tel.: +1-530-754-7501; Fax: +1-530-754-5125.

Received: 29 March 2013; in revised form: 6 June 2013 / Accepted: 6 June 2013 / Published: 26 June 2013

\begin{abstract}
Traumatic brain injury (TBI) is a leading cause of death and disability in the United States. Despite more than 30 years of research, no pharmacological agents have been identified that improve neurological function following TBI. However, several lines of research described in this review provide support for further development of voltage gated calcium channel (VGCC) antagonists as potential therapeutic agents. Following TBI, neurons and astrocytes experience a rapid and sometimes enduring increase in intracellular calcium $\left(\left[\mathrm{Ca}^{2+}\right]_{\mathrm{i}}\right)$. These fluxes in $\left[\mathrm{Ca}^{2+}\right]_{\mathrm{i}}$ drive not only apoptotic and necrotic cell death, but also can lead to long-term cell dysfunction in surviving cells. In a limited number of in vitro experiments, both L-type and N-type VGCC antagonists successfully reduced calcium loads as well as neuronal and astrocytic cell death following mechanical injury. In rodent models of TBI, administration of VGCC antagonists reduced cell death and improved cognitive function. It is clear that there is a critical need to find effective therapeutics and rational drug delivery strategies for the management and treatment of TBI, and we believe that further investigation of VGCC antagonists should be pursued before ruling out the possibility of successful translation to the clinic.
\end{abstract}

Keywords: voltage-gated calcium channels; antagonists; ziconotide; nimodipine; traumatic brain injury 


\section{Introduction}

\subsection{Significance of Traumatic Brain Injury}

It is estimated that well over 5.3 million people live in the United States with deficits related to traumatic brain injury (TBI) [1], with over 1.7 new TBI cases annually. A recent meta-analysis examining the prevalence of TBI in the general adult population found that that approximately $12 \%$ of the general adult population has a history of TBI with loss of consciousness $(16.7 \%$ for males and $8.5 \%$ for females) [2]. Many patients suffering severe [3-5] as well as mild or moderate TBI [5-7] are unable to return to work, maintain steady employment, and they struggle with daily tasks due to persistent cognitive deficits. In fact, in a recent study by the TBI Model Systems National Data Centre only $38 \%$ of patients followed were employed 2-years following their TBI [8]. Approximately $\$ 48.3$ billion dollars is spent on TBI patient care in the US each year, with over $\$ 31.7$ billion (65\%) for those that survive [9]. The annual cost for new cases of acute TBI care and rehabilitation is estimated to be approximately $\$ 10$ billion in the U.S. alone. To date, no effective pharmacotherapy has been shown to improve outcome following TBI, in spite of intensive research in this area [10]. Therefore, the need to develop effective drugs for TBI continues to be pressing. In this paper we review the role of voltage gated calcium channels (VGCC) in the pathophysiology of TBI, and evidence that antagonists of VGCC can be neuroprotective in animal models of TBI and may have potential for clinical use.

\subsection{Regulation of Intracellular Calcium}

Calcium ions $\left(\mathrm{Ca}^{2+}\right)$ are major regulators of vital cellular functions. Through their interactions with specific calcium binding proteins, including calmodulin, parvalbumin, calbindin and calretinin, calcium ions are involved in the regulation of secretory functions (e.g., neurotransmitters, hormones), enzyme activity, intracellular transport, contractile processes, glycolysis, respiration, mitosis, membrane potential and intracellular communication [11-15]. These functions are critical for cell survival and disruption of calcium regulation can be catastrophic for the cell. It is therefore not surprising that interference with $\mathrm{Ca}^{2+}$ homeostasis contributes to cell injury and death in a number of pathological conditions, including traumatic brain injury [16]. In fact, calcium has been called the "final common pathway" for toxic cell death [17].

Intracellular cytosolic calcium levels are maintained at low resting levels between 50-100 nM via the combined activity of VGCC's, receptor operated channels (ROC), store operated channels (SOC), calcium-ATPase transporters in the plasma membrane (PMCA) and smooth endoplasmic reticulum (SERCA), as well as the $\mathrm{Na}^{+} / \mathrm{Ca}^{2+}$ exchanger in endoplasmic reticulum, mitochondria and plasma membrane. Some inorganic calcium is also bound to bicarbonate, phosphate and phosphatides. Intracellular stores contained within the endoplasmic reticulum and mitochondria also influence cytosolic calcium levels. For example, receptor-generated inositol triphosphate $\left(\mathrm{IP}_{3}\right)$ can release calcium from stores within the endoplasmic reticulum [18,19] and ryanodine receptor activation on the endoplasmic reticulum and mitochondria represent an additional important source of intracellular $\mathrm{Ca}^{2+}[20]$. 


\section{Voltage Gated Calcium Channels}

\subsection{Voltage Gated Calcium Channel Structure}

Voltage-gated calcium channels are heteromultimers formed by an $\alpha_{1}$ subunit and three auxiliary subunits $\alpha_{2}-\delta, \beta$, and $\gamma$ [21] (Figure 1). The $\alpha_{1}$ subunit is the largest (190-250 kDa) and incorporates the conduction pore, voltage sensor and gating apparatus. It is also the major site of channel regulation by second messengers, drugs, and toxins. The $\alpha_{1}$ subunit is comprised of four homologous domains composed of six transmembrane helical segments (S1-S6) that determine key channel characteristics [21]. For example, the S4 segment functions as the voltage sensor and the pore loop between segments S5 and S6 determines ion selectivity and conductance. Ten distinct $\alpha_{1}$ subunits have been described, associated with six different classes of VGCCs [22-26]. In addition there are also several ancillary proteins $(\beta, \alpha 2 \delta$, and $\gamma)$ associated with the $\alpha 1$ subunit that form a multimeric complex (see Figure 1). These ancillary subunits modify the biophysical properties of the VGCC, second messenger modulation and intracellular transport [27,28]. Finally, there is a growing literature related to the structure and function of splice variants of the L- [29,30], N- [31], P/Q- [31], R- [32] and T-type [33] VGCCs. In fact there is evidence that alternate splice variants of both the L- [34,35] and N-type [36] VGCC can influence the affinity and/or sensitivity of channels to specific antagonists.

Figure 1. Subunit structure of voltage gated calcium channels (VGCC). The $\alpha 1$ is the pore-forming subunit which contains voltage-sensing machinery and the binding sites of channel blockers. $\alpha_{1}$ subunit contains 4 homologous domains (I-IV), each containing 6 transmembrane helices (S1-S6). The $\alpha 2 \delta$ and $\beta$ subunits enhance expression and modulate the voltage dependence and gating kinetics of VGCCs.

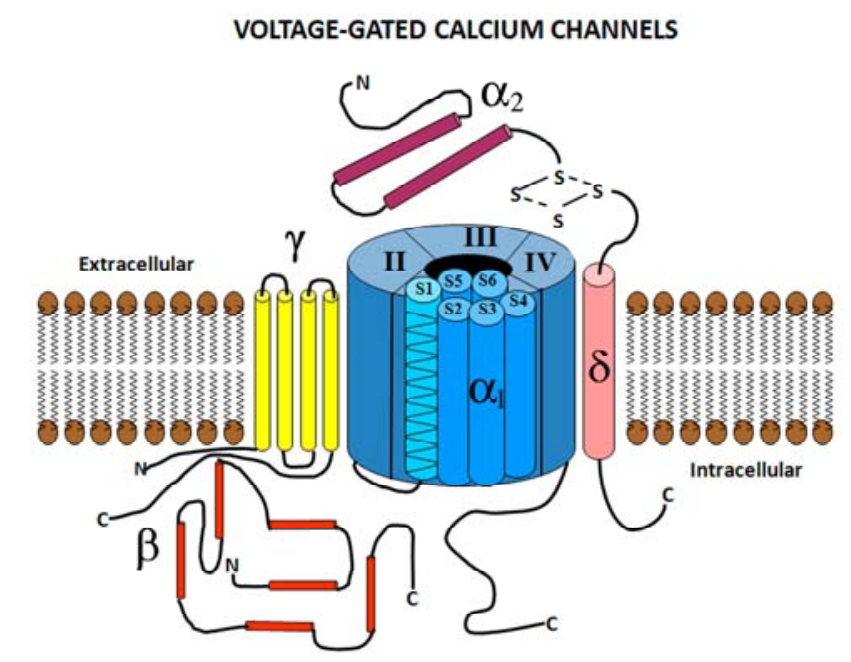

\subsection{Voltage Gated Calcium Channel Subtypes}

Classification of the six subtypes of VGCCs was originally based on their biophysical and pharmacological properties (Table 1). They are typically referred to as L-, N-, P-, Q-, R- and T-type channels [22,23,25,37]. However, a newer gene-based nomenclature is in use [38]. Under the new nomenclature L-type channels are designed $\mathrm{Ca}_{\mathrm{v}} 1.1-1.4, \mathrm{P} / \mathrm{Q}$ as $\mathrm{Ca}_{\mathrm{v}} 2.1, \mathrm{~N}$ as $\mathrm{Ca}_{\mathrm{v}} 2.2, \mathrm{R}$ as $\mathrm{Ca}_{\mathrm{v}}$ 2.3, and T-type channels as $\mathrm{Ca}_{\mathrm{v}}$ 3.1-3.3. It addition there is evidence of addition R-type $\mathrm{Ca}^{2+}$ current that is separate from the $\mathrm{Ca}_{\mathrm{v}} 2.3$ channel [39]. 
Table 1. Summary of the properties and common antagonists of voltage-gated calcium channel blockers.

\begin{tabular}{|c|c|c|c|c|c|c|c|}
\hline Channel Type & $\begin{array}{c}L \\
\mathrm{Ca}_{\mathrm{v}} 1.1-1.4\end{array}$ & $\begin{array}{c}\mathrm{N} \\
\mathrm{Ca}_{\mathrm{v}} 2.2\end{array}$ & $\begin{array}{c}\mathbf{P} \\
\mathrm{Ca}_{\mathrm{v}} 2.1\end{array}$ & $\begin{array}{c}Q \\
\mathrm{Ca}_{\mathrm{v}} 2.1\end{array}$ & $\begin{array}{c}\mathbf{R} \\
\mathrm{Ca}_{\mathbf{v}} 2.3\end{array}$ & $\begin{array}{c}\mathrm{T} \\
\mathrm{Ca}_{\mathrm{v}} 3.1-3.3\end{array}$ & Ref. \\
\hline Conductance (pS) & 25 & 11 to 20 & 9 to 20 & 15 to 16 & 15 to 20 & 8 & {$[40]$} \\
\hline Selectivity $\left(\mathrm{Ca}^{2+}>\mathrm{Ba}^{2+}\right)$ & $2: 1$ & $2: 1$ & $2: 1$ & ND & $1.3: 1$ & $1: 1$ & [40] \\
\hline Activation Potential (mV) & -10 to -50 & -20 & -50 & -50 & -25 to -40 & -70 & [40] \\
\hline $\begin{array}{l}\text { Inactivation Kinetics } \\
(\mathrm{msec})\end{array}$ & $150-2,000$ & $100-200$ & $500-1,000$ & $500-1,000$ & $50-100$ & $10-70$ & [40] \\
\hline \multicolumn{8}{|l|}{ Calcium Blockers (IC50) } \\
\hline$\omega$-conotoxin MVIIA & None & $78 \mathrm{nM}-1 \mu \mathrm{M}$ & None & None & None & None & {$[40-42]$} \\
\hline$\omega$-conotoxin GVIA & None & $28 \mathrm{nM}-2 \mu \mathrm{M}$ & None & None & None & None & {$[40-42]$} \\
\hline$\omega$-Agatoxin AgaIVA & None & None & $15 \mathrm{nM}$ & $50 \mathrm{nM}-1 \mu \mathrm{M}$ & $50 \mathrm{~nm}$ & None & {$[41,43]$} \\
\hline$\omega$-conotoxin MVIIC & None & $18 \mathrm{nM}$ & $18 \mathrm{nM}$ & $50 \mathrm{nM}-1 \mu \mathrm{M}$ & None & None & {$[41,44]$} \\
\hline$\omega$-Agatoxin AgaIIIA & $1 \mathrm{~nm}$ & $1 \mathrm{~nm}$ & IC50 N/A & IC50 N/A & None & None & {$[45]$} \\
\hline SNX-482 & None & None & $30-750 \mathrm{~nm}$ & $30-750 \mathrm{~nm}$ & $15-30 \mathrm{nM}$ & None & {$[41,46,47]$} \\
\hline Nimodipine & $\begin{array}{c}0.135-2.6 \\
\mu \mathrm{M}\end{array}$ & None & None & None & None & $5-11 \mu \mathrm{M}$ & [48-51] \\
\hline Nifedipine & $100 \mathrm{nM}$ & None & None & None & None & $39 \mu \mathrm{M}$ & {$[50]$} \\
\hline Efonidipine & $10 \mu \mathrm{M}$ & None & None & None & None & $1.3-13 \mu \mathrm{M}$ & [51-53] \\
\hline Amplodipine & $3-5 \mu \mathrm{M}$ & None & None & None & None & $4-13 \mu \mathrm{M}$ & {$[51,54,55]$} \\
\hline Nicardipine & $9-26 \mu \mathrm{M}$ & None & $32-97 \mu \mathrm{M}$ & $32-97 \mu \mathrm{M}$ & None & $5-13 \mu \mathrm{M}$ & [55] \\
\hline Verapamil & $0.6-1 \mu \mathrm{M}$ & None & None & None & None & $20-30 \mu \mathrm{M}$ & {$[49,56,57]$} \\
\hline Diltiazem & $3-33 \mu \mathrm{M}$ & None & None & None & None & $30 \mu \mathrm{M}$ & {$[49,57]$} \\
\hline Mibefradil & $1.7-21 \mu \mathrm{M}$ & None & $208 \mu \mathrm{M}$ & $208 \mu \mathrm{M}$ & None & $0.5-11 \mu \mathrm{M}$ & {$[51,58,59]$} \\
\hline
\end{tabular}


For simplicity we will retain the older nomenclature in this review (i.e., L, N, P, Q, R \& T). As shown in the table above, the various channels differ in their conductance rates, voltage activation threshold, and rate of inactivation. A complete review of calcium channel biophysics is beyond the scope of this review. However, L-type channels are high-threshold, large-conductance, slowly inactivating calcium channels [35]. The L-type channel is well understood pharmacologically and defined by its sensitivity to blockade by dihydropyridines such as nimodipine. The N-, P, Q and R-type voltage gated calcium channels are intermediate, having medium conductances, intermediate inactivation kinetics, and medium to high activation thresholds [21]. These calcium channels are selectively blocked by various snail and spider toxins as summarized above. The T-type channel is a low-threshold, low-conductance, rapidly inactivating calcium channel [60]. T-type channels can be blocked by Mibefradil with a 10-30 times higher potency than L-type channels [61,62]. All six types of VGCC's are found in brain, with the L, N-, P- and Q- and R-type channels involved in synaptic transmission [21]. The N, P, Q and R-type channels are also critically involved in regulating calciumdependent neurotransmitter release from presynaptic terminals, while the L- and T-type channels appear to make little contribution to this process [24]. The low-voltage activated T-type channel appears to be primarily involved in the generation of rhythmic burst firing of neurons, and is thought to contribute to network synchrony and epilepsy [63].

\subsection{Voltage Gated Calcium Channel Distribution in the Nervous System}

The distributions of VGCCs in mammalian brain have been examined by receptor autoradiography [64,65] and immunocytochemistry [66-68]. L-type VGCC's are widely distributed in muscle, endocrine cells and brain, but are less abundant in neuronal tissues compared to other VGCC's [23]. N-type VGCC's show a wide distribution in rodent brain, with highest densities found in cerebral cortex, dendritic zones of the hippocampus, amygdala, septal nuclei, medial geniculate, superior colliculus, molecular layers of cerebellar cortex, n. solitary tract and spinal cord (layers 1-3) [23,64,66,67,69]. P/Q-type calcium channels, although not as widely distributed as N-type channels, are located on cerebellar granule cells, interneurons and Purkinje cells, and in the hippocampus on pyramidal and granule cells [25,66]. While less well described, there is evidence of R-type VGCC in the cortex [70], thalamus [71], and hippocampus [72,73]. T-type VGCC's have been demonstrated in cerebellum, thalamus, olfactory bulb and hippocampus [74]. At the cellular level N and P/Q-type VGCC's are found both pre- and post-synaptically, and interact directly with presynaptic core proteins syntaxin and SNAP-25, providing a molecular basis for $\mathrm{Ca}^{+2}$ influx into nerve terminals and transmitter release $[75,76]$. Astrocytes have L- and possibly T-type channels, while, to date, VGCCs have not been observed on mature oligodendrocytes [77].

\subsection{Characterizing Voltage Gated Calcium Channels Based on Pharmacology}

Dihydropyridine antagonists (e.g., nimodipine, nifedipine, verapamil, amlodipine) robustly block L-type channels [78]. While originally it was thought that the remaining VGCC were dihydropyridine insensitive, it was demonstrated in Xenopus oocytes that several of these blockers (including amlodipine) also antagonized N-, P- and Q-type channels at higher concentrations [55]. It was also observed that the dihydropyridine efonidipine inhibits not only the L- but also the T-type VGCC [79]. Finally, it has recently been suggested that, at the concentrations used, the effect of dihydropyridines on the R-type channel have been occluded. Specifically, at a $500 \mathrm{~nm}$ concentration, isradipine was able 
to partially antagonize the R-type current in cardiomyocytes [80]. In conclusion, while the ability of dihydropyridines to antagonize L-type channels is undisputed, these compounds appear to have effects across the spectrum of VGCC. It is clear, therefore, that more research is warranted into the antagonism of each of the VGCC subtypes by dihydropyridines. The N-, P- and Q-type channels can be blocked by specific $\omega$-conotoxins and $\omega$-agatoxins $[24,25,81]$. The $\omega$-conotoxins or $\omega$-conopeptides are basic, water soluble, 24-29 amino acid peptides isolated from the venom of fish-hunting marine snails belonging to the genus Conus [81]. The best-characterized are the $\omega$-conotoxins GVIA, TVIA (SNX185) and MVIIA (i.e., SNX111) that block the N-type calcium channel [24,82]. A large number of highly selective analogs (e.g., SNX111 and SNX185) have been synthesized and carry the designation "SNX" in the literature. The $\omega$-agatoxin AgaIVA is isolated from the venom of funnel-web spiders and is a potent blocker of P- $\left(\mathrm{K}_{d} 1-3 \mathrm{nM}\right)$ and Q-type $\left(\mathrm{K}_{\mathrm{d}} 90 \mathrm{nM}\right)$ VGCC's. The P- and Q-type VGCC's are differentiated pharmacologically by their sensitivity, but not selectivity to AgaIVA [24]. The N-, P- and Q-type channels are all blocked by the $\omega$-conotoxin MVIIC [24]. The R-type VGCC's are resistant to $\omega$-conotoxins and $\omega$-agatoxins, but have been reported to be blocked by a selective inhibitor SNX-482 although the selectivity of SNX-482 for T-type VGCCs has recently been challenged [83-85]. T-type blockers include several dihydropyridine antagonists including efonidipine, felodipine and nitrendipine $[51,61,86]$ as well as nimodipine [51]. Mibefradil has also been identified as a potent T-type channel blocker [87]. There is also evidence that specific heavy metals have the ability to block VGCC including lead for L-type [88], nickel [89] and zinc [90] for T-type, and zinc and copper for R-type channels [91]. To date, antagonism of either L-Type ( $\alpha_{1 S}$ and $\left.\alpha_{1 \mathrm{D}}\right)$ or N-type $\left(\alpha_{1 \mathrm{~B}}\right)$ channels has been evaluated as a strategy for improving outcome following TBI, but similar studies have not yet been carried out with blockers of P/Q, T or R-type VGCCs.

\section{Experimental Evidence that Blockade of VGCC’s Can be Neuroprotective}

\subsection{Pathological Calcium Accumulation Following TBI}

The pathophysiology of TBI has typically been separated into primary and secondary injuries. Primary injury occurs at the time of impact as a result of mechanical tissue deformation resulting in contusions, lacerations, shearing of axonal connections and hemorrhage. Primary injury also initiates a cascade of secondary injury mechanisms, including a large influx of calcium into damaged cells, which can trigger further cell death and lead to substantially increased morbidity [17,92-96].

There is ample experimental evidence that intracellular calcium overload occurs after brain injury, and is a key early step in the activation of secondary injury mechanisms (Figure 2) [17,92-96]. Several in vitro studies have documented a large increase in $\left[\mathrm{Ca}^{2+}\right]_{\mathrm{i}}$ that occurs following traumatic injury to neurons and astrocytes in culture [97-107]. Calcium influx from injury in neurons can result from activation of the N-methyl-D-Aspartate (NMDA) receptor [105,108-111], opening of VGCCs [102,110,112], as well as release from intracellular stores $[16,103,113]$. Accumulation of $\left[\mathrm{Ca}^{2+}\right]_{\mathrm{i}}$ in astrocytes has also been demonstrated to come from release from intracellular stores [99,113] as well as the activation of the sodium calcium exchanger [98]. Many in vitro studies have now demonstrated that disruption of calcium homeostasis can injure cells or lead to cell death and have implicated a variety of cellular mechanisms (Figure 2). These include in activation of apoptotic pathways [114-119], mitochondrial dysfunction [120-124], free radical production [125] lipid peroxidation [126,127] and osmotic disturbances [128]. In cultures, mechanical strain injury not only increased acute $\left[\mathrm{Ca}^{2+}\right]$, but also 
triggered delayed depolarization lasting up to $24 \mathrm{~h}$ following injury [129]. Consequences of increased calcium uptake include significant neuronal [100,105,112,130,131] and astrocytic [98,101,132] cell death as well as persistent neuronal dysfunction [133-138]. Second insults such as hypoxia [112,139], and ischemia [139-143] can lead to additional and extended accumulation of $\left[\mathrm{Ca}^{2+}\right]_{i}$ which is associated with further diminished outcome [112].

Figure 2. Schematic describing the role of VGCC in TBI-induced neuronal and astorcytic cell death.

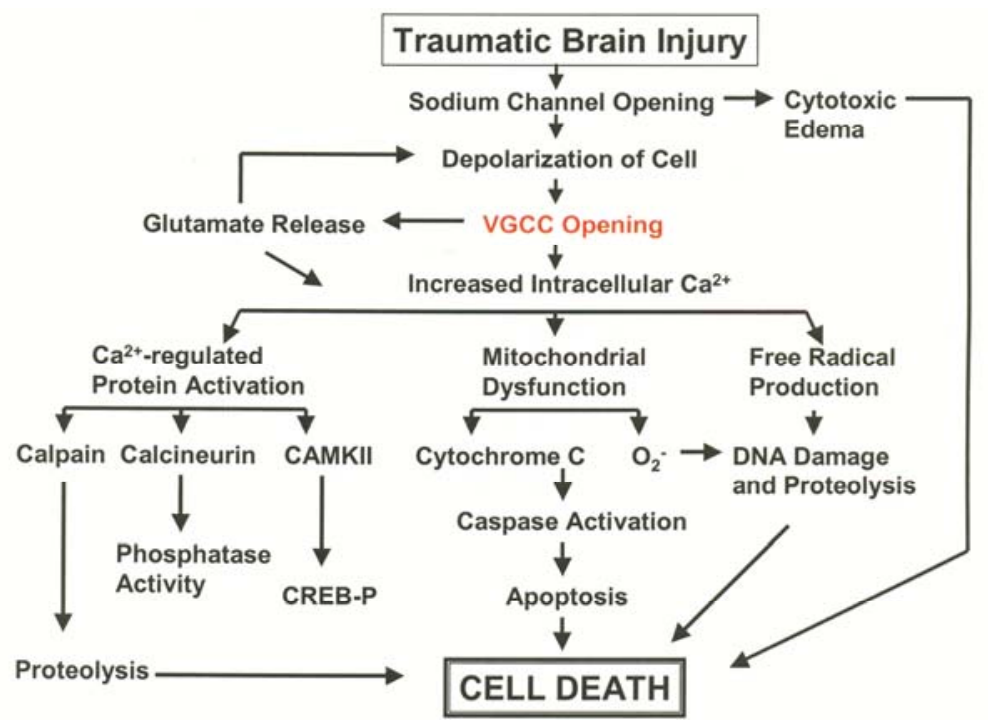

In vivo studies, although far fewer in number, also support the involvement of calcium influx following traumatic injury to the spinal cord and brain. Extracellular calcium levels fall dramatically immediately after spinal cord injury [95,144], while total tissue levels of calcium increase [107]. Nilsson and colleagues, using calcium sensitive electrodes, identified immediate and dramatic decreases in extracellular calcium at the focus of injury in a weight-drop model of cortical contusion in rats. The authors concluded that massive $\mathrm{Ca}^{2+}$ entry into the intracellular compartment occurring at the site of injury was responsible for this phenomenon [145]. Dienel [146] used ${ }^{45} \mathrm{Ca}^{2+}$ autoradiography to map increased cellular levels of calcium after transient forebrain ischemia in rats, and argued that such results were due to an accumulation of intracellular calcium after injury. Following lateral fluid percussion, assessment of ${ }^{45} \mathrm{Ca}^{2+}$ using autoradiography indicated not only an acute increase of calcium in the injured cortex and hippocampus, but a sustained accumulation lasting for several days post-injury. Furthermore, a more diffuse ${ }^{45} \mathrm{Ca}^{2+}$ accumulation was also detected in the thalamus that could be observed for up to two weeks following injury [147,148]. Using the lateral fluid percussion model of TBI, DeLorenzo and colleagues acutely isolated injured hippocampal neurons in culture and imaged calcium fluxes using the calcium sensitive dye Fura-2-AM. In these preparations $\left[\mathrm{Ca}^{2+}\right]_{\mathrm{i}}$ levels remained elevated for at least one week following fluid percussion TBI and calcium homeostasis was impaired for at least 30 days, indicating that TBI has enduring effects on $\mathrm{Ca}^{2+}$ dynamics $[149,150]$. These pre-clinical studies document the significant increase in $\left[\mathrm{Ca}^{2+}\right]_{i}$ that follows TBI, and point to the possibility that pharmacological interventions aimed at reducing the rise in $\left[\mathrm{Ca}^{2+}\right]_{\mathrm{I}}$, such as antagonism of VGCC (Figure 2), could be a rational and effective therapeutic strategy to reduce cell death and dysfunction. 


\subsection{L-Type VGCC Antagonists to Treat Traumatic Brain Injury}

The L-type VGCCs require strong depolarization for activation, and are typically related to long-lasting calcium currents [21]. L-type VGCCs are prominent in the vertebrate cardiac, skeletal and smooth muscle. In the central nervous system, they are located on the cell body and proximal and distal dendrites [66,151]. There are three classes of L-type VGCC antagonists including phenalkylamines (verapamil, D-600), benzothiazepine (dlitiazem) and dihydropyridines (nimodipine, nifedipine, nitrendipine) [21]. Pre-clinical rodent [152-155] and primate [156] studies demonstrated the utility of nimodipine to improve cerebral blood flow, reduce infarct volume and improve behavioral outcome following an ischemic injury. Importantly, improved outcome was observed in the absence of significant drug side effects. Clinical trials to translate nimodipine to treat the acute effects of ischemia found significant improvements in both blood flow and outcome following injury [157-159].

Despite the promising clinical evidence for the potential of L-type antagonists to improve outcome following an ischemic insult, there is significantly less data evaluating these compounds in traumatic brain injury. Initial in vitro studies found that nimodipine reduced cell death following treatment with high concentrations of glutamate [160]. In in vitro cell culture models of uniaxial and bi-axial mechanical strain injury, a cocktail of a sodium channel blocker (tetrodotoxin, TTX) NMDA antagonist ((2R)-amino-5-phosphonopentanoate; APV), AMPA antagonist (6-cyano-7-nitroquinoxaline-2,3-dione; CNQX), and nimodipine applied prior to strain significantly reduced the average accumulation of $\left[\mathrm{Ca}^{2+}\right]_{\mathrm{i}}$ in neurons as well as the total number of neurons experiencing significant $\left[\mathrm{Ca}^{2+}\right]_{\mathrm{i}}$ load [130]. In a different model of mechanical injury, nifedipine significantly reduced cell death and improved cell function in an organotypic hippocampal slice culture [97]. In initial in vivo studies, verapamil administered following a lateral fluid percussion traumatic brain injury in rats significantly improved cerebral blood flow in the injured cortex leading the authors to conclude that L-type VGCC play a role in vasoconstriction and the loss of vasoreactivity following TBI [161]. In a separate study, nimodipine treatment was able to reduce lipid peroxidation caused by traumatic brain injury in rodents [162]. Considering the extensive literature on the accumulation of $\left[\mathrm{Ca}^{2+}\right]_{\mathrm{i}}$ and the loss of $\mathrm{Ca}^{2+}$ homeostasis, there is sparse pre-clinical data evaluating the potential of L-type VGCC antagonists to improve outcome following TBI.

Even with such limited pre-clinical evidence, L-type VGCC antagonists have been tested in several clinical trials in patients with severe TBI examining their potential to improve outcome when administered systemically acutely following injury. In initial clinical trials (HIT 1) it was observed that intravenous delivery of nimodipine had modest effects on outcome with only a trend toward improved outcome $[163,164]$. The authors also noted that the drug was well tolerated and patients experienced few side effects. In a follow up study (HIT II) [165] these same authors reached a similar conclusion that nimodipine had modest effects on patients with severe TBI. However the authors made an additional observation; nimodipine was more efficacious in patients with evidence of traumatic subarachnoid hemorrhage from their initial CT scan. However subsequent studies have failed to find a similar beneficial effect even within this subpopulation [166,167]. A more recent study reported that cerebral metabolism and outcome were improved in a small patient population by intravenous nimodipine treatment $[168,169]$. Therefore, there continues to be considerable uncertainty about a beneficial effect of nimodipine treatment for acute traumatic brain injury [170]. In summary, to date, antagonists of L-type VGCC have failed to provide convincing evidence that blockade of L-type VGCCs is an effective therapeutic strategy for TBI. 


\subsection{N-Type VGCC Antagonists to Treat Traumatic Brain Injury}

N-type VGCCs are activated by strong depolarization, and are found on the dendrites, soma, and axon terminals of neurons [67,171-173]. These VGCCs located at axon terminals play a critical role in neurotransmitter release throughout the central nervous system [172,174], and may play a dominant role in norepinephrine release from sympathetic neurons [175]. In 1985 Olivera and colleagues described small peptides isolated from the venoms of cone snails that were very specific and potent inhibitors of N-type VGCCs [25,69,81]. One sub-class, the $\omega$-conotoxins, MVIIA was found to be highly selective for the N-type VGCC, and a synthetic form of the toxin called ziconotide (also known as SNX-111, Prialt ${ }^{\circledR}$ ) was developed and has been used in studies of pain systems, ischemia and TBI [176-179]. Similar to L-type antagonists, initial characterization of ziconotide was on improving outcome in rodent models of ischemia [180-182]. Unlike L-type antagonists, however, the focus of ziconotide treatment was neuroprotection and not blood flow.

Because of their role in neurotransmitter release, N-type VGCCs represent an attractive target for neuroprotection through their ability to reduce excitatory neurotransmitter release and there by prevent or limit excitotoxic cell damage by glutamate. However, there have been relatively few pre-clinical studies of the potential of N-type VGCC antagonists in experimental models of TBI. A recent in vitro study, using a mechanical strain-injury model of TBI in mixed neuronal glial cultures, examined the effects of the selective N-type VGCC blocker SNX-185 on $\left[\mathrm{Ca}^{2+}\right]_{\mathrm{i}}$ imaged with Fura-2-AM and neuronal and astrocyte survival after injury by immunohistochemistry. SNX-185 is a synthetic form of $\omega$-conotoxin TVIA and is similar to MVIIA (i.e., ziconotide) in its selectivity for N-type VGCCs. Addition of SNX-185 to the culture media before or immediately (i.e., $<5 \mathrm{sec}$ ) after mechanical straininjury significantly reduced the rise in $\left[\mathrm{Ca}^{2+}\right]_{\mathrm{i}}$ and improved survival of injured neurons and astrocytes following mild, moderate or severe mechanical strain injury [102]. Concentrations of 100 and 1000 nM SNX-185 in the culture media appeared to be equally effective. Delayed addition of SNX-185 to the media 5 min after mechanical strain injury did not improve cell survival nor did it prevent the rise in $\left[\mathrm{Ca}^{2+}\right]_{\mathrm{i}}$. However, these results would be expected because in the in vitro mechanical strain-injury model the peak increase in $\left[\mathrm{Ca}^{2+}\right]_{\mathrm{i}}$ occurs within a few seconds to a minute after injury, before the 5 min delayed treatment with SNX-185. However, mechanical injury does lead to extended elevations in $\left[\mathrm{Ca}^{2+}\right]_{\mathrm{i}}[16,104,105]$. Interestingly, treatment with SNX-185 facilitated the return of injured neurons to more normal calcium homeostasis. Specifically, elevated levels of $\left[\mathrm{Ca}^{2+}\right]_{\mathrm{i}}$ following strain injury returned to near baseline levels (i.e., $100 \mathrm{nM}$ ) significantly sooner in injured neurons when SNX-185 was added to the bath media 5 min after injury.

Because $\left[\mathrm{Ca}^{2+}\right]_{\mathrm{i}}$ can remain elevated for long periods of time after injury, these results suggest that that N-type VGCC blockers may prevent the rise in $\left[\mathrm{Ca}^{2+}\right]_{\mathrm{i}}$ for cells that may be injured but show a delayed rise in $\left[\mathrm{Ca}^{2+}\right]_{\mathrm{i}}$ and facilitate the return of calcium homeostasis. However, it remains to be demonstrated experimentally whether calcium homeostasis is normal or whether or not the return to baseline calcium levels would be beneficial to injured cells. Microdialysis samples taken from these cultures demonstrated a significant reduction in extracellular glutamate [102] suggesting that, in part, SNX-185 was decreasing calcium accumulation by blocking presynaptic N-type calcium channels and thereby reducing pre-synaptic glutamate release. Recently, these same authors tested whether SNX-185 would have similar effects in an in vitro model of mechanical injury with hypoxia as a second insult [112]. Hypoxia was produced by changing the cell culture $\mathrm{CO}_{2}$ level from $5 \%$ (normoxic) to $20 \%$ (i.e., hypoxic) after mechanical strain injury, and then carrying out calcium imaging with 
Fura-2-AM 3, 6 and $24 \mathrm{~h}$ later. Compared to the normoxic condition, hypoxia further increased the rise of $\left[\mathrm{Ca}^{2+}\right]$ after injury at all three imaging time points, and resulted in greater cell death across all mechanical strain injury severities. Addition of $1 \mu \mathrm{M}$ SNX-185 $5 \mathrm{~min}$ after the second insult reduced the added effects of hypoxia on $\left[\mathrm{Ca}^{2+}\right]$ as well as the effects of hypoxia on cell survival, resulting in great numbers of surviving neurons. These results point to the importance of secondary insults in the pathophysiology of TBI and further support continued research and development of N-type VGCC antagonists to improve outcome in TBI patients at risk for second insult. In an in vitro model of axonal injury in which the opening of stretch-activated sodium channels in axons was followed by an increase in calcium accumulation, damage to the injured axon was prevented by either blocking sodium channels with tetratrodotoxin or blockade of VGCCs by the omega-conotoxin MVIIC [106].

In vivo studies with ziconotide, the synthetic version of MVIIA, have also demonstrated neuroprotective activity in rodent models of TBI. When administered i.v. $1 \mathrm{~h}$ following lateral fluid percussion TBI, ziconotide significantly reduced the increase in ${ }^{45} \mathrm{Ca}^{2}$ accumulation in the dorsal hippocampus for up to $48 \mathrm{~h}$ following injury, with less dramatic effects observed in the cortex [183]. In a follow up study the same authors found that intravenous ziconotide dramatically reduced ${ }^{45} \mathrm{Ca}^{2+}$ accumulation in the ipsilateral cortex (by 75\%), but also several other brain regions including ipsilateral thalamus and hippocampus (up to 50\%) [184]. In the rat model of controlled cortical impact TBI, an accumulation of $\mathrm{Ca}^{2+}$ was found in mitochondria along with significant mitochondria respiratory dysfunction for up to $48 \mathrm{~h}$ following injury [124]. Intravenous administration of ziconotide within $4 \mathrm{~h}$ from the time of injury significantly improved mitochondrial respiration in the injured brain [185-187]. Mitochondrial function was restored even when ziconoitde was delivered $10 \mathrm{~h}$ following the lateral fluid percussion injury [185]. Repeated intravenous injections of ziconotide at 3, 6 , and $12 \mathrm{~h}$ after an impact-acceleration model of diffuse axonal traumatic brain injury in rats significantly improved cognitive and sensory-motor function [179]. In a more recent study, direct stereotaxic injection of SNX-185 into the dorsal hippocampus 5 min following lateral fluid percussion brain injury significantly reduced neuronal loss in the ipsilateral hippocampus and improved motor and cognitive function [188]. However, in a recent study, extracellular glutamate was significantly elevated in the striatum for up to $48 \mathrm{~h}$ following midline fluid percussion TBI in rats [189], and the rise in glutamate was not blocked by the N-type VGCC blocker GVIA, suggesting that the elevated striatal glutamate following TBI may not be calcium-dependent.

Although the preclinical data were limited and the exact neuroprotective mechanisms of ziconotide were not well understood, a phase II human safety, efficacy, and feasibility trial of intravenous ziconitide in severe TBI patients was initiated. Unfortunately the study was halted before completion due to complicating cardiovascular (i.e., hypotension) effects of systemic ziconotide treatment, likely due to the effects of N-type antagonists on heart rate and blood pressure [190,191], and the results of this trial have not been published. Therefore, the potential for clinical development of N-type VGCC blockers remains an open question, one that should be further explored given the established role of calcium in cell injury following TBI, the established efficacy of N-type VGCC blockers in limiting intracellular calcium accumulation, and the strength of the preclinical data in in vitro and in vivo studies. 


\section{Conclusions}

\subsection{Lessons to be Learned from Ziconotide Development for Chronic Pain}

To date there has been a failure to translate pre-clinical therapeutic strategies from bench to the bedside to treat patients with TBI. A great deal has been written about this dilemma and several recommendations have come from careful analyses of recent failures [10]. First, experimental treatments should target known mechanisms of secondary injury following TBI and the dosages used should be adequate to block the targeted injury mechanism. Second, the effectiveness of the treatment should be demonstrated in animal models of brain injury, and the therapeutic window and optimal duration of treatment should be established. Third, valid outcome measures should be used. Finally, safety of the treatment for eventual use in patients with TBI should be demonstrated.

These recommendations and the development and clinical approval of intrathecal ziconotide for treatment of intractable pain offer lessons for the development of drugs, such as ziconotide, for use in TBI. As in TBI studies, initial findings in rodents [176-178,192] and in primates [176] indicated the potential for ziconotide to reduce chronic pain in the absence of significant side effects. However, initial trials to translate ziconotide to the bedside were not successful due to significant peripheral side effects of the calcium channel blocker in a limited clinical study, including substantial hypotension following systemic administration [193]. However, rather than abandoning zicontide for pain management, the intrathecal route of administration was adopted that provided pain relief at a lower dose and did not produce significant cardiovascular or central CNS effects. Currently intrathecal ziconotide, now available as Prialt, has been used successfully in patients to treat acute post-operative pain [194], AIDS-related pain, cancer-related pain [195], and severe chronic pain [196]. In the most recent trials, ziconotide was found to be both efficacious and safe for continuous administration over at least a three-year period [197,198]. Based on the evidence reviewed above it would seem reasonable to continue development of N-type VGCC blockers, including ziconotide and SNX-185, to improve motor and cognitive function following TBI.

\subsection{Summary}

Based on the limited pre-clinical data, we feel that specific L- and N-type VGCC antagonists continue to have translational potential for pharmacotherapy in TBI patients. Furthermore, there have been no specific studies addressing the role that P/Q, R and T-type VGCC play in the pathophysiology of traumatic brain injury. The mechanisms of action for antagonists for each of these channels have been well defined, and their bioavailability and pharmacokinetics have been characterized. There is substantial preclinical data supporting further development of N-type VGCC blockers for use in TBI [199]. To date, however, only a very limited number of pre-clinical experiments have evaluated the potential of either L- or N-type VGCC antagonists to improve outcome following TBI. There is also evidence that R-type VGCC may increase the constriction of arteries improving outcome in rodent models of subarachnoid hemorrhage [200] and that the R-type antagonist SNX-482 can improve blood flow in the days following injury [201]. Future studies should also include other N-type VGCC blockers such as SNX-185, antagonists of other VGCC (i.e., P/Q, R or T-type channels), the use of lower doses to avoid or reduce complications due to systemic side effects. In addition, as demonstrated in the treatment for chronic pain, intrathecal delivery of ziconotide can reduce the effect of channel 
antagonists on peripheral targets such as the heart and vasculature. This is relevant not only for N-type channels but also R- [200,202], T- [202], P/Q- [202-204] and L-type channels [202,205] that also may alter global heart rate and/or blood flow when administered systemically. There may also be potential for VGCC antagonists to improve function following TBI in cases where patients endure second insults, such as hypoxia, ischemia or seizures. However, based on the recommendation from Bullock and colleagues [10], it is clear that further pre-clinical evaluation is necessary in order to design a wellinformed clinical trial.

\section{Conflict of interest}

The authors hold no conflict of interest.

\section{References}

1. Faul, M.; Xu, L.; Wald, M.M.; Coronado, V.G. Traumatic Brain Injury in the United States: Emergency Department Visits, Hospitalizations and Deaths 2002-2006; Centers for Disease Control and Prevention: Atlanta, GA, USA, 2010.

2. Frost, R.B.; Farrer, T.J.; Primosch, M.; Hedges, D.W. Prevalence of traumatic brain injury in the general adult population: A meta-analysis. Neuroepidemiology 2012, 40, 154-159.

3. Brooks, D.N.; Aughton, M.E. Cognitive recovery during the first year after severe blunt head injury. Int. Rehabil. Med. 1979, 1, 166-172.

4. Brooks, N.; McKinlay, W.; Symington, C.; Beattie, A.; Campsie, L. Return to work within the first seven years of severe head injury. Brain Inj. 1987, 1, 5-19.

5. Benedictus, M.R.; Spikman, J.M.; van der Naalt, J. Cognitive and behavioral impairment in traumatic brain injury related to outcome and return to work. Arch. Phys. Med. Rehabil. 2010, 91, 1436-1441.

6. Bootes, K.; Chapparo, C. Difficulties with multitasking on return to work after TBI: A critical case study. Work 2010, 36, 207-216.

7. Gilworth, G.; Eyres, S.; Carey, A.; Bhakta, B.B.; Tennant, A. Working with a brain injury: Personal experiences of returning to work following a mild or moderate brain injury. J. Rehabil. Med. 2008, 40, 334-339.

8. Shigaki, C.L.; Johnstone, B.; Schopp, L.H. Financial and vocational outcomes 2 years after traumatic brain injury. Disabil. Rehabil. 2009, 31, 484-489.

9. Lewin, J.; Sumners, D. Anorexia due to brain injury. Brain Inj. 1992, 6, 199-201.

10. Bullock, M.R.; Lyeth, B.G.; Muizelaar, J.P. Current status of neuroprotection trials for traumatic brain injury: Lessons from animal models and clinical studies. Neurosurgery 1999, 45, 207-217; discussion 217-220.

11. Petersen, O.H.; Michalak, M.; Verkhratsky, A. Calcium signalling: Past, present and future. Cell Calcium 2005, 38, 161-169.

12. Carafoli, E. Intracellular calcium homeostasis. Annu. Rev. Biochem. 1987, 56, 395-433.

13. Miller, R.J. The control of neuronal $\mathrm{Ca}^{2+}$ homeostasis. Prog. Neurobiol. 1991, 37, 255-285.

14. Racay, P.; Kaplan, P.; Lehotsky, J. Control of $\mathrm{Ca}^{2+}$ homeostasis in neuronal cells. Gen. Physiol. Biophys. 1996, 15, 193-210. 
15. Racay, P.; Lehotsky, J. Intracellular and molecular aspects of $\mathrm{Ca}(2+)$-mediated signal transduction in neuronal cells. Gen. Physiol. Biophys. 1996, 15, 273-289.

16. Weber, J.T. Calcium homeostasis following traumatic neuronal injury. Curr. Neurovasc. Res. 2004, 1, 151-171.

17. Schanne, F.A.; Kane, A.B.; Young, E.E.; Farber, J.L. Calcium dependence of toxic cell death: A final common pathway. Science 1979, 206, 700-702.

18. Berridge, M.J.; Irvine, R.F. Inositol phosphates and cell signalling. Nature 1989, 341, 197-205.

19. Carafoli, E.; Longoni, S. The plasma membrane in the control of the signaling function of calcium. Soc. Gen. Physiol. Ser. 1987, 42, 21-29.

20. Campbell, K.P.; Knudson, C.M.; Imagawa, T.; Leung, A.T.; Sutko, J.L.; Kahl, S.D.; Raab, C.R.; Madson, L. Identification and characterization of the high affinity [3h]ryanodine receptor of the junctional sarcoplasmic reticulum $\mathrm{Ca}^{2+}$ release channel. J. Biol. Chem. 1987, 262, 6460-6463.

21. Hille, B. Ion Channels of Excitable Membranes, 3rd ed.; Sinauer Associates, Inc.: Sunderland, MA, USA, 2001; Chapter xviii, pp. 814, 818.

22. Catterall, W.A. Structure and function of voltage-gated ion channels. Annu. Rev. Biochem. 1995, 64, 493-531.

23. Dunlap, K.; Luebke, J.I.; Turner, T.J. Exocytotic $\mathrm{Ca}^{2+}$ channels in mammalian central neurons. Trends Neurosci. 1995, 18, 89-98.

24. Miljanich, G.P.; Ramachandran, J. Antagonists of neuronal calcium channels: Structure, function, and therapeutic implications. Annu. Rev. Pharmacol. Toxicol. 1995, 35, 707-734.

25. Olivera, B.M.; Miljanich, G.P.; Ramachandran, J.; Adams, M.E. Calcium channel diversity and neurotransmitter release: The omega-conotoxins and omega-agatoxins. Annu. Rev. Biochem. 1994, 63, 823-867.

26. Tsien, R.W.; Nilius, B. Cardiac calcium currents at the level of single channels. Experientia 1987, 43, 1169-1172.

27. Cain, S.M.; Snutch, T.P. Voltage-gated calcium channels and disease. BioFactors 2011, 37, 197-205.

28. Dolphin, A.C. Calcium channel auxiliary alpha2delta and beta subunits: Trafficking and one step beyond. Nat. Rev. Neurosci. 2012, 13, 542-555.

29. Kim, H.L.; Kim, H.; Lee, P.; King, R.G.; Chin, H. Rat brain expresses an alternatively spliced form of the dihydropyridine-sensitive L-type calcium channel alpha 2 subunit. Proc. Natl. Acad. Sci. USA 1992, 89, 3251-3255.

30. Perez-Reyes, E.; Wei, X.Y.; Castellano, A.; Birnbaumer, L. Molecular diversity of L-type calcium channels. Evidence for alternative splicing of the transcripts of three non-allelic genes. J. Biol. Chem. 1990, 265, 20430-20436.

31. Allen, S.E.; Darnell, R.B.; Lipscombe, D. The neuronal splicing factor nova controls alternative splicing in N-type and P-type Cav2 calcium channels. Channels 2010, 4, 483-489.

32. Williams, M.E.; Marubio, L.M.; Deal, C.R.; Hans, M.; Brust, P.F.; Philipson, L.H.; Miller, R.J.; Johnson, E.C.; Harpold, M.M.; Ellis, S.B. Structure and functional characterization of neuronal alpha 1e calcium channel subtypes. J. Biol. Chem. 1994, 269, 22347-22357. 
33. Senatore, A.; Spafford, J.D. Gene transcription and splicing of T-type channels are evolutionarily-conserved strategies for regulating channel expression and gating. PLoS One 2012, 7, e37409.

34. Zhang, H.Y.; Liao, P.; Wang, J.J.; Yu de, J.; Soong, T.W. Alternative splicing modulates diltiazem sensitivity of cardiac and vascular smooth muscle $\mathrm{Ca}(\mathrm{v}) 1.2$ calcium channels. $\mathrm{Br}$. $J$. Pharmacol. 2010, 160, 1631-1640.

35. Zuccotti, A.; Clementi, S.; Reinbothe, T.; Torrente, A.; Vandael, D.H.; Pirone, A. Structural and functional differences between 1-type calcium channels: Crucial issues for future selective targeting. Trends Pharmacol. Sci. 2011, 32, 366-375.

36. Helton, T.D.; Kojetin, D.J.; Cavanagh, J.; Horne, W.A. Alternative splicing of a beta4 subunit proline-rich motif regulates voltage-dependent gating and toxin block of Cav2.1 $\mathrm{Ca}^{2+}$ channels. J. Neurosci. 2002, 22, 9331-9339.

37. Catterall, W.A. Voltage-gated calcium channels. Cold Spring Harbor Perspectives in Biology 2011, 3, a003947.

38. Ertel, E.A.; Campbell, K.P.; Harpold, M.M.; Hofmann, F.; Mori, Y.; Perez-Reyes, E.; Schwartz, A.; Snutch, T.P.; Tanabe, T.; Birnbaumer, L.; et al. Nomenclature of voltage-gated calcium channels. Neuron 2000, 25, 533-535.

39. Sochivko, D.; Pereverzev, A.; Smyth, N.; Gissel, C.; Schneider, T.; Beck, H. The Ca(v)2.3 $\mathrm{Ca}(2+)$ channel subunit contributes to R-type $\mathrm{Ca}(2+)$ currents in murine hippocampal and neocortical neurones. J. Physiol. 2002, 542, 699-710.

40. Sharman, J.L.; Benson, H.E.; Pawson, A.J.; Lukito, V.; Mpamhanga, C.P.; Bombail, V.; Davenport, A.P.; Peters, J.A.; Spedding, M.; Harmar, A.J.; et al. IUPHAR-DB: Updated database content and new features. Nucl. Acids Res. 2013, 41, 1083-1088.

41. Pringos, E.; Vignes, M.; Martinez, J.; Rolland, V. Peptide neurotoxins that affect voltage-gated calcium channels: A close-up on omega-agatoxins. Toxins 2011, 3, 17-42.

42. Bowman, D.; Alexander, S.; Lodge, D. Pharmacological characterisation of the calcium channels coupled to the plateau phase of kcl-induced intracellular free $\mathrm{Ca}^{2+}$ elevation in chicken and rat synaptosomes. Neuropharmacology 1993, 32, 1195-1202.

43. Stephens, G.J.; Page, K.M.; Burley, J.R.; Berrow, N.S.; Dolphin, A.C. Functional expression of rat brain cloned alphale calcium channels in cos-7 cells. Pflugers Arch. 1997, 433, 523-532.

44. McDonough, S.I.; Swartz, K.J.; Mintz, I.M.; Boland, L.M.; Bean, B.P. Inhibition of calcium channels in rat central and peripheral neurons by omega-conotoxin mviic. J. Neurosci. 1996, 16, 2612-2623.

45. Ertel, E.A.; Warren, V.A.; Adams, M.E.; Griffin, P.R.; Cohen, C.J.; Smith, M.M. Type iii omega-agatoxins: A family of probes for similar binding sites on L- and N-type calcium channels. Biochemistry 1994, 33, 5098-5108.

46. Arroyo, G.; Aldea, M.; Fuentealba, J.; Albillos, A.; Garcia, A.G. Snx482 selectively blocks P/Q $\mathrm{Ca}^{2+}$ channels and delays the inactivation of $\mathrm{Na}^{+}$channels of chromaffin cells. Eur. J. Pharmacol. 2003, 475, 11-18.

47. Lu, Z.J.; Pereverzev, A.; Liu, H.L.; Weiergraber, M.; Henry, M.; Krieger, A.; Smyth, N.; Hescheler, J.; Schneider, T. Arrhythmia in isolated prenatal hearts after ablation of the Cav2.3 (alpha1e) subunit of voltage-gated $\mathrm{Ca}^{2+}$ channels. Cell. Phys. Biochem. 2004, 14, 11-22. 
48. Xu, W.; Lipscombe, D. Neuronal Ca(v)1.3alpha(1) 1-type channels activate at relatively hyperpolarized membrane potentials and are incompletely inhibited by dihydropyridines. J. Neurosci. 2001, 21, 5944-5951.

49. Catterall, W.A.; Perez-Reyes, E.; Snutch, T.P.; Striessnig, J. International Union Of Pharmacology. XLVIII. Nomenclature and structure-function relationships of voltage-gated calcium channels. Pharm. Rev. 2005, 57, 411-425.

50. Stengel, W.; Jainz, M.; Andreas, K. Different potencies of dihydropyridine derivatives in blocking T-type but not L-type $\mathrm{Ca}^{2+}$ channels in neuroblastoma-glioma hybrid cells. Eur. J. Pharmacol. 1998, 342, 339-345.

51. Furukawa, T.; Nukada, T.; Namiki, Y.; Miyashita, Y.; Hatsuno, K.; Ueno, Y.; Yamakawa, T.; Isshiki, T. Five different profiles of dihydropyridines in blocking $\mathrm{T}$-type $\mathrm{Ca}(2+)$ channel subtypes (Ca(v)3.1 (alpha(1g)), $\mathrm{Ca}(\mathrm{v}) 3.2$ (alpha(1h)), and $\mathrm{Ca}(\mathrm{v}) 3.3$ (alpha(1i))) expressed in Xenopus oocytes. Eur. J. Pharmacol. 2009, 613, 100-107.

52. Horiba, M.; Muto, T.; Ueda, N.; Opthof, T.; Miwa, K.; Hojo, M.; Lee, J.K.; Kamiya, K.; Kodama, I.; Yasui, K. T-type $\mathrm{Ca}^{2+}$ channel blockers prevent cardiac cell hypertrophy through an inhibition of calcineurin-nfat 3 activation as well as L-type $\mathrm{Ca}^{2+}$ channel blockers. Life Sci. 2008, 82, 554-560.

53. Masumiya, H.; Kase, J.; Tanaka, Y.; Tanaka, H.; Shigenobu, K. Frequency-dependent blockade of T-type Ca2+ current by efonidipine in cardiomyocytes. Life Sci. 2000, 68, 345-351.

54. Kwan, Y.W.; Bangalore, R.; Lakitsh, M.; Glossmann, H.; Kass, R.S. Inhibition of cardiac L-type calcium channels by quaternary amlodipine: Implications for pharmacokinetics and access to dihydropyridine binding site. J. Mol. Cell Cardiol. 1995, 27, 253-262.

55. Furukawa, T.; Yamakawa, T.; Midera, T.; Sagawa, T.; Mori, Y.; Nukada, T. Selectivities of dihydropyridine derivatives in blocking $\mathrm{Ca}(2+)$ channel subtypes expressed in Xenopus oocytes. J. Pharmacol. Exp. Ther. 1999, 291, 464-473.

56. Freeze, B.S.; McNulty, M.M.; Hanck, D.A. State-dependent verapamil block of the cloned human $\mathrm{Ca}(\mathrm{v}) 3.1$ T-type $\mathrm{Ca}(2+)$ channel. Mol. Pharmacol. 2006, 70, 718-726.

57. Kuga, T.; Sadoshima, J.; Tomoike, H.; Kanaide, H.; Akaike, N.; Nakamura, M. Actions of Ca ${ }^{2+}$ antagonists on two types of $\mathrm{Ca}^{2+}$ channels in rat aorta smooth muscle cells in primary culture. Circ. Res. 1990, 67, 469-480.

58. Xi, Q.; Angus, J.A. Evidence against an action of mibefradil at N-type voltage-operated calcium channels. Naunyn Schmiedebergs Arch. Pharmacol. 2001, 364, 430-436.

59. Aczel, S.; Kurka, B.; Hering, S. Mechanism of voltage- and use-dependent block of class a $\mathrm{Ca}^{2+}$ channels by mibefradil. Br. J. Pharmacol. 1998, 125, 447-454.

60. Perez-Reyes, E.; Lory, P. Molecular biology of T-type calcium channels. CNS Neurol. Disord. Drug Targets 2006, 5, 605-609.

61. Perez-Reyes, E.; Van Deusen, A.L.; Vitko, I. Molecular pharmacology of human Cav3.2 T-type $\mathrm{Ca}^{2+}$ channels: Block by antihypertensives, antiarrhythmics, and their analogs. J. Pharmacol. Exp. Ther. 2009, 328, 621-627.

62. McDonough, S.I.; Bean, B.P. Mibefradil inhibition of T-type calcium channels in cerebellar purkinje neurons. Mol. Pharmacol. 1998, 54, 1080-1087. 
63. Cain, S.M.; Snutch, T.P. T-type calcium channels in burst-firing, network synchrony, and epilepsy. Biochim. Biophys. Acta 2013, 1828, 1572-1578.

64. Takemura, M.; Kiyama, H.; Fukui, H.; Tohyama, M.; Wada, H. Autoradiographic visualization in rat brain of receptors for omega-conotoxin gvia, a newly discovered calcium antagonist. Brain Res. 1988, 451, 386-389.

65. Takemura, M.; Kiyama, H.; Fukui, H.; Tohyama, M.; Wada, H. Distribution of the omegaconotoxin receptor in rat brain. An autoradiographic mapping. Neuroscience 1989, 32, 405-416.

66. Timmermann, D.B.; Westenbroek, R.E.; Schousboe, A.; Catterall, W.A. Distribution of high-voltage-activated calcium channels in cultured gamma-aminobutyric acidergic neurons from mouse cerebral cortex. J. Neurosci. Res. 2002, 67, 48-61.

67. Westenbroek, R.E.; Sakurai, T.; Elliott, E.M.; Hell, J.W.; Starr, T.V.; Snutch, T.P.; Catterall, W.A. Immunochemical identification and subcellular distribution of the alpha 1a subunits of brain calcium channels. J. Neurosci. 1995, 15, 6403-6418.

68. Nakanishi, S.; Fujii, A.; Kimura, T.; Sakakibara, S.; Mikoshiba, K. Spatial distribution of omegaagatoxin IVA binding sites in mouse brain slices. J. Neurosci. Res. 1995, 41, 532-539.

69. McCleskey, E.W.; Fox, A.P.; Feldman, D.H.; Cruz, L.J.; Olivera, B.M.; Tsien, R.W.; Yoshikami, D. Omega-conotoxin: Direct and persistent blockade of specific types of calcium channels in neurons but not muscle. Proc. Natl. Acad. Sci. USA 1987, 84, 4327-4331.

70. Rhee, J.S.; Ishibashi, H.; Akaike, N. Calcium channels in the gabaergic presynaptic nerve terminals projecting to meynert neurons of the rat. J. Neurochem. 1999, 72, 800-807.

71. Zaman, T.; Lee, K.; Park, C.; Paydar, A.; Choi, J.H.; Cheong, E.; Lee, C.J.; Shin, H.S. Cav2.3 channels are critical for oscillatory burst discharges in the reticular thalamus and absence epilepsy. Neuron 2011, 70, 95-108.

72. Muller, R.; Struck, H.; Ho, M.S.; Brockhaus-Dumke, A.; Klosterkotter, J.; Broich, K.; Hescheler, J.; Schneider, T.; Weiergraber, M. Atropine-sensitive hippocampal theta oscillations are mediated by Cav2.3 R-type $\mathrm{Ca}(2+)$ channels. Neuroscience 2012, 205, 125-139.

73. Weiergraber, M.; Kamp, M.A.; Radhakrishnan, K.; Hescheler, J.; Schneider, T., The Ca(v)2.3 voltage-gated calcium channel in epileptogenesis - Shedding new light on an enigmatic channel. Neurosci. Biobehav. Rev. 2006, 30, 1122-1144.

74. Klugbauer, N.; Lacinova, L.; Marais, E.; Hobom, M.; Hofmann, F. Molecular diversity of the calcium channel alpha2delta subunit. J. Neurosci. 1999, 19, 684-691.

75. Rettig, J.; Sheng, Z.H.; Kim, D.K.; Hodson, C.D.; Snutch, T.P.; Catterall, W.A. Isoform-specific interaction of the alpha1a subunits of brain $\mathrm{Ca}^{2+}$ channels with the presynaptic proteins syntaxin and snap-25. Proc. Natl. Acad. Sci. USA 1996, 93, 7363-7368.

76. Sheng, Z.H.; Yokoyama, C.T.; Catterall, W.A. Interaction of the synprint site of N-type $\mathrm{Ca}^{2+}$ channels with the c2b domain of synaptotagmin I. Proc. Natl. Acad. Sci. USA 1997, 94, 5405-5410.

77. Verkhratsky, A.; Steinhauser, C. Ion channels in glial cells. Brain Res. Brain Res. Rev. 2000, 32, 380-412.

78. Moreno Davila, H. Molecular and functional diversity of voltage-gated calcium channels. Ann. N. Y. Acad. Sci. 1999, 868, 102-117. 
79. Masumiya, H.; Shijuku, T.; Tanaka, H.; Shigenobu, K. Inhibition of myocardial L- and T-type $\mathrm{Ca}^{2+}$ currents by efonidipine: Possible mechanism for its chronotropic effect. Eur. J. Pharmacol. 1998, 349, 351-357.

80. Galetin, T.; Tevoufouet, E.E.; Sandmeyer, J.; Matthes, J.; Nguemo, F.; Hescheler, J.; Weiergraber, M.; Schneider, T. Pharmacoresistant Ca(v) 2.3 (E-type/R-type) voltage-gated calcium channels influence heart rate dynamics and may contribute to cardiac impulse conduction. Cell Biochem. Funct. 2012, doi:10.1002/cbf.2918.

81. Olivera, B.M.; Gray, W.R.; Zeikus, R.; McIntosh, J.M.; Varga, J.; Rivier, J.; de Santos, V.; Cruz, L.J. Peptide neurotoxins from fish-hunting cone snails. Science 1985, 230, 1338-1343.

82. Adams, D.J.; Berecki, G. Mechanisms of conotoxin inhibition of N-type (Ca2.2) calcium channels. Biochim. Biophys. Acta 2013, in press.

83. D'Ascenzo, M.; Vairano, M.; Andreassi, C.; Navarra, P.; Azzena, G.B.; Grassi, C. Electrophysiological and molecular evidence of L-(Cav1), N- (Cav2.2), and R- (Cav2.3) type $\mathrm{Ca}^{2+}$ channels in rat cortical astrocytes. Glia 2004, 45, 354-363.

84. Newcomb, R.; Szoke, B.; Palma, A.; Wang, G.; Chen, X.; Hopkins, W.; Cong, R.; Miller, J.; Urge, L.; Tarczy-Hornoch, K.; et al. Selective peptide antagonist of the class E calcium channel from the venom of the tarantula hysterocrates gigas. Biochemistry 1998, 37, 15353-15362.

85. Wang, G.; Dayanithi, G.; Newcomb, R.; Lemos, J.R. An R-type Ca(2+) current in neurohypophysial terminals preferentially regulates oxytocin secretion. J. Neurosci. 1999, 19, 9235-9241.

86. Furukawa, T.; Nukada, T.; Miura, R.; Ooga, K.; Honda, M.; Watanabe, S.; Koganesawa, S.; Isshiki, T. Differential blocking action of dihydropyridine $\mathrm{Ca}^{2+}$ antagonists on a T-type $\mathrm{Ca}^{2+}$ channel (alpha1g) expressed in Xenopus oocytes. J. Cardiovasc. Pharmacol. 2005, 45, 241-246.

87. Clozel, J.P.; Ertel, E.A.; Ertel, S.I. Discovery and main pharmacological properties of mibefradil (RO 40-5967), the first selective T-type calcium channel blocker. J. Hypertens. Suppl. 1997, 15, S17-S25.

88. Bernal, J.; Lee, J.H.; Cribbs, L.L.; Perez-Reyes, E. Full reversal of Pb++ block of L-type Ca++ channels requires treatment with heavy metal antidotes. J. Pharmacol. Exp. Ther. 1997, 282, $172-180$.

89. Lee, J.H.; Gomora, J.C.; Cribbs, L.L.; Perez-Reyes, E. Nickel block of three cloned T-type calcium channels: Low concentrations selectively block alphalh. Biophys. J. 1999, 77, 3034-3042.

90. Nelson, M.T.; Woo, J.; Kang, H.W.; Vitko, I.; Barrett, P.Q.; Perez-Reyes, E.; Lee, J.H.; Shin, H.S.; Todorovic, S.M. Reducing agents sensitize c-type nociceptors by relieving high-affinity zinc inhibition of T-type calcium channels. J. Neurosci. 2007, 27, 8250-8260.

91. Shcheglovitov, A.; Vitko, I.; Lazarenko, R.M.; Orestes, P.; Todorovic, S.M.; Perez-Reyes, E. Molecular and biophysical basis of glutamate and trace metal modulation of voltage-gated Ca(v)2.3 calcium channels. J. Gen. Physiol. 2012, 139, 219-234.

92. Siesjo, B.K. Calcium and cell death. Magnesium 1989, 8, 223-237.

93. Siesjo, B.K.; Agardh, C.D.; Bengtsson, F. Free radicals and brain damage. Cerebrovasc. Brain Metab. Rev. 1989, 1, 165-211.

94. Siesjo, B.K.; Bengtsson, F.; Grampp, W.; Theander, S. Calcium, excitotoxins, and neuronal death in the brain. Ann. N. Y. Acad. Sci. 1989, 568, 234-251. 
95. Young, W. Role of calcium in central nervous system injuries. J Neurotrauma 1992, 9 (Suppl 1), S9-S25.

96. Nilsson, P.; Laursen, H.; Hillered, L.; Hansen, A.J. Calcium movements in traumatic brain injury: The role of glutamate receptor-operated ion channels. J Cereb. Blood. Flow. Metab. 1996, 16, 262-270.

97. Cater, H.L.; Gitterman, D.; Davis, S.M.; Benham, C.D.; Morrison, B., 3rd; Sundstrom, L.E. Stretch-induced injury in organotypic hippocampal slice cultures reproduces in vivo post-traumatic neurodegeneration: Role of glutamate receptors and voltage-dependent calcium channels. J. Neurochem. 2007, 101, 434-447.

98. Floyd, C.L.; Gorin, F.A.; Lyeth, B.G. Mechanical strain injury increases intracellular sodium and reverses $\mathrm{Na}^{+} / \mathrm{Ca}^{2+}$ exchange in cortical astrocytes. Glia 2005, 51, 35-46.

99. Floyd, C.L.; Rzigalinski, B.A.; Weber, J.T.; Sitterding, H.A.; Willoughby, K.A.; Ellis, E.F. Traumatic injury of cultured astrocytes alters inositol (1,4,5)-trisphosphate-mediated signaling. Glia 2001, 33, 12-23.

100. LaPlaca, M.C.; Thibault, L.E. An in vitro traumatic injury model to examine the response of neurons to a hydrodynamically-induced deformation. Ann. Biomed. Eng. 1997, 25, 665-677.

101. Rzigalinski, B.A.; Weber, J.T.; Willoughby, K.A.; Ellis, E.F. Intracellular free calcium dynamics in stretch-injured astrocytes. J. Neurochem. 1998, 70, 2377-2385.

102. Shahlaie, K.; Lyeth, B.G.; Gurkoff, G.G.; Muizelaar, J.P.; Berman, R.F. Neuroprotective effects of selective N-type VGCC blockade on stretch-injury-induced calcium dynamics in cortical neurons. J. Neurotrauma 2010, 27, 175-187.

103. Staal, J.A.; Dickson, T.C.; Gasperini, R.; Liu, Y.; Foa, L.; Vickers, J.C. Initial calcium release from intracellular stores followed by calcium dysregulation is linked to secondary axotomy following transient axonal stretch injury. J. Neurochem. 2010, 112, 1147-1155.

104. Weber, J.T.; Rzigalinski, B.A.; Ellis, E.F. Traumatic injury of cortical neurons causes changes in intracellular calcium stores and capacitative calcium influx. J. Biol. Chem. 2001, 276, 1800-1807.

105. Weber, J.T.; Rzigalinski, B.A.; Willoughby, K.A.; Moore, S.F.; Ellis, E.F. Alterations in calcium-mediated signal transduction after traumatic injury of cortical neurons. Cell Calcium 1999, 26, 289-299.

106. Wolf, J.A.; Stys, P.K.; Lusardi, T.; Meaney, D.; Smith, D.H. Traumatic axonal injury induces calcium influx modulated by tetrodotoxin-sensitive sodium channels. J. Neurosci. 2001, 21, 1923-1930.

107. Young, W.; Koreh, I. Potassium and calcium changes in injured spinal cords. Brain Res. 1986, 365, 42-53.

108. Ahmed, S.M.; Weber, J.T.; Liang, S.; Willoughby, K.A.; Sitterding, H.A.; Rzigalinski, B.A.; Ellis, E.F. Nmda receptor activation contributes to a portion of the decreased mitochondrial membrane potential and elevated intracellular free calcium in strain-injured neurons. J. Neurotrauma 2002, 19, 1619-1629.

109. Geddes, D.M.; LaPlaca, M.C.; Cargill, R.S., 2nd Susceptibility of hippocampal neurons to mechanically induced injury. Exp. Neurol. 2003, 184, 420-427. 
110. Geddes-Klein, D.M.; Serbest, G.; Mesfin, M.N.; Cohen, A.S.; Meaney, D.F. Pharmacologically induced calcium oscillations protect neurons from increases in cytosolic calcium after trauma. J. Neurochem. 2006, 97, 462-474.

111. LaPlaca, M.C.; Thibault, L.E. Dynamic mechanical deformation of neurons triggers an acute calcium response and cell injury involving the n-methyl-d-aspartate glutamate receptor. J. Neurosci. Res. 1998, 52, 220-229.

112. Shahlaie, K.; Gurkoff, G.G.; Lyeth, B.G.; Muizelaar, J.P.; Berman, R.F. Neuroprotective effects of SNX-185 in an in vitro model of TBI with a second insult. Restor. Neurol. Neurosci. 2013, 31, 141-153.

113. Chen, T.; Willoughby, K.A.; Ellis, E.F. Group I metabotropic receptor antagonism blocks depletion of calcium stores and reduces potentiated capacitative calcium entry in strain-injured neurons and astrocytes. J. Neurotrauma 2004, 21, 271-281.

114. Buki, A.; Okonkwo, D.O.; Wang, K.K.; Povlishock, J.T. Cytochrome C release and caspase activation in traumatic axonal injury. J. Neurosci. 2000, 20, 2825-2834.

115. Conti, A.C.; Raghupathi, R.; Trojanowski, J.Q.; McIntosh, T.K. Experimental brain injury induces regionally distinct apoptosis during the acute and delayed post-traumatic period. J. Neurosci. 1998, 18, 5663-5672.

116. Eldadah, B.A.; Faden, A.I. Caspase pathways, neuronal apoptosis, and CNS injury. J. Neurotrauma 2000, 17, 811-829.

117. Keane, R.W.; Kraydieh, S.; Lotocki, G.; Alonso, O.F.; Aldana, P.; Dietrich, W.D. Apoptotic and antiapoptotic mechanisms after traumatic brain injury. J. Cereb. Blood. Flow. Metab. 2001, 21, 1189-1198.

118. Newcomb, J.K.; Zhao, X.; Pike, B.R.; Hayes, R.L. Temporal profile of apoptotic-like changes in neurons and astrocytes following controlled cortical impact injury in the rat. Exp. Neurol. 1999, 158, 76-88.

119. Raghupathi, R.; Graham, D.I.; McIntosh, T.K. Apoptosis after traumatic brain injury. J. Neurotrauma 2000, 17, 927-938.

120. Robertson, C.L.; Puskar, A.; Hoffman, G.E.; Murphy, A.Z.; Saraswati, M.; Fiskum, G. Physiologic progesterone reduces mitochondrial dysfunction and hippocampal cell loss after traumatic brain injury in female rats. Exp. Neurol. 2006, 197, 235-243.

121. Robertson, C.L.; Saraswati, M.; Fiskum, G. Mitochondrial dysfunction early after traumatic brain injury in immature rats. J. Neurochem. 2007, 101, 1248-1257.

122. Singh, I.N.; Sullivan, P.G.; Deng, Y.; Mbye, L.H.; Hall, E.D. Time course of post-traumatic mitochondrial oxidative damage and dysfunction in a mouse model of focal traumatic brain injury: Implications for neuroprotective therapy. J. Cereb. Blood. Flow. Metab. 2006, 26, 1407-1418.

123. White, R.J.; Reynolds, I.J. Mitochondria accumulate $\mathrm{Ca}^{2+}$ following intense glutamate stimulation of cultured rat forebrain neurones. J. Physiol. 1997, 498 (Pt 1), 31-47.

124. Xiong, Y.; Gu, Q.; Peterson, P.L.; Muizelaar, J.P.; Lee, C.P. Mitochondrial dysfunction and calcium perturbation induced by traumatic brain injury. J. Neurotrauma 1997, 14, 23-34.

125. Mustafa, A.G.; Singh, I.N.; Wang, J.; Carrico, K.M.; Hall, E.D. Mitochondrial protection after traumatic brain injury by scavenging lipid peroxyl radicals. J. Neurochem 2010, 114, 271-280. 
126. Braughler, J.M.; Duncan, L.A.; Goodman, T. Calcium enhances in vitro free radical-induced damage to brain synaptosomes, mitochondria, and cultured spinal cord neurons. J. Neurochem 1985, 45, 1288-1293.

127. Braughler, J.M.; Hall, E.D. Involvement of lipid peroxidation in CNS injury. J. Neurotrauma 1992, 9 (Suppl 1), S1-S7.

128. Odland, R.M.; Sutton, R.L. Hyperosmosis of cerebral injury. Neurological Res. 1999, 21, 500-508.

129. Tavalin, S.J.; Ellis, E.F.; Satin, L.S. Mechanical perturbation of cultured cortical neurons reveals a stretch-induced delayed depolarization. J. Neurophysiol. 1995, 74, 2767-2773.

130. Geddes-Klein, D.M.; Schiffman, K.B.; Meaney, D.F. Mechanisms and consequences of neuronal stretch injury in vitro differ with the model of trauma. J. Neurotrauma 2006, 23, 193-204.

131. Lusardi, T.A.; Wolf, J.A.; Putt, M.E.; Smith, D.H.; Meaney, D.F. Effect of acute calcium influx after mechanical stretch injury in vitro on the viability of hippocampal neurons. J. Neurotrauma 2004, 21, 61-72.

132. Rzigalinski, B.A.; Liang, S.; McKinney, J.S.; Willoughby, K.A.; Ellis, E.F. Effect of $\mathrm{Ca}^{2+}$ on in vitro astrocyte injury. J. Neurochem. 1997, 68, 289-296.

133. Goforth, P.B.; Ellis, E.F.; Satin, L.S. Mechanical injury modulates AMPA receptor kinetics via an NMDA receptor-dependent pathway. J. Neurotrauma 2004, 21, 719-732.

134. Goforth, P.B.; Ellis, E.F.; Satin, L.S. Enhancement of AMPA-mediated current after traumatic injury in cortical neurons. J. Neurosci 1999, 19, 7367-7374.

135. Goforth, P.B.; Ren, J.; Schwartz, B.S.; Satin, L.S. Excitatory synaptic transmission and network activity are depressed following mechanical injury in cortical neurons. J. Neurophys. 2011, 105, 2350-2363.

136. Spaethling, J.; Le, L.; Meaney, D.F. NMDA receptor mediated phosphorylation of GluR1 subunits contributes to the appearance of calcium-permeable AMPA receptors after mechanical stretch injury. Neurobiol. Dis. 2012, 46, 646-654.

137. Spaethling, J.M.; Klein, D.M.; Singh, P.; Meaney, D.F. Calcium-permeable AMPA receptors appear in cortical neurons after traumatic mechanical injury and contribute to neuronal fate. J. Neurotrauma 2008, 25, 1207-1216.

138. Gurkoff, G.G.; Shahlaie, K.; Lyeth, B.G. In vitro mechanical strain trauma alters neuronal calcium responses: Implications for posttraumatic epilepsy. Epilepsia 2012, 53 (Suppl 1), 53-60.

139. DeWitt, D.S.; Jenkins, L.W.; Prough, D.S. Enhanced vulnerability to secondary ischemic insults after experimental traumatic brain injury. New. Horiz. 1995, 3, 376-383.

140. Bullock, R.; Zauner, A.; Woodward, J.J.; Myseros, J.; Choi, S.C.; Ward, J.D.; Marmarou, A.; Young, H.F. Factors affecting excitatory amino acid release following severe human head injury. J. Neurosurg. 1998, 89, 507-518.

141. Katayama, Y.; Kawamata, T.; Tamura, T.; Hovda, D.A.; Becker, D.P.; Tsubokawa, T. Calciumdependent glutamate release concomitant with massive potassium flux during cerebral ischemia in vivo. Brain Res. 1991, 558, 136-140.

142. Kochanek, P.M. Ischemic and traumatic brain injury: Pathobiology and cellular mechanisms. Crit. Care Med. 1993, 21, S333-S335. 
143. Engel, D.C.; Slemmer, J.E.; Vlug, A.S.; Maas, A.I.; Weber, J.T. Combined effects of mechanical and ischemic injury to cortical cells: Secondary ischemia increases damage and decreases effects of neuroprotective agents. Neuropharmacology 2005, 49, 985-995.

144. Stokes, B.T.; Fox, P.; Hollinden, G. Extracellular calcium activity in the injured spinal cord. Exp. Neurol. 1983, 80, 561-572.

145. Nilsson, P.; Hillered, L.; Olsson, Y.; Sheardown, M.J.; Hansen, A.J. Regional changes in interstitial $\mathrm{K}^{+}$and $\mathrm{Ca}^{2+}$ levels following cortical compression contusion trauma in rats. J. Cereb. Blood Flow Metab. 1993, 13, 183-192.

146. Dienel, G.A. Regional accumulation of calcium in postischemic rat brain. J. Neurochem. 1984, 43, 913-925.

147. Fineman, I.; Hovda, D.A.; Smith, M.; Yoshino, A.; Becker, D.P. Concussive brain injury is associated with a prolonged accumulation of calcium: A 45Ca autoradiographic study. Brain Res. 1993, 624, 94-102.

148. Osteen, C.L.; Moore, A.H.; Prins, M.L.; Hovda, D.A. Age-dependency of 45calcium accumulation following lateral fluid percussion: Acute and delayed patterns. J. Neurotrauma 2001, 18, 141-162.

149. Deshpande, L.S.; Sun, D.A.; Sombati, S.; Baranova, A.; Wilson, M.S.; Attkisson, E.; Hamm, R.J.; DeLorenzo, R.J. Alterations in neuronal calcium levels are associated with cognitive deficits after traumatic brain injury. Neurosci. Lett. 2008, 441, 115-119.

150. Sun, D.A.; Deshpande, L.S.; Sombati, S.; Baranova, A.; Wilson, M.S.; Hamm, R.J.; DeLorenzo, R.J. Traumatic brain injury causes a long-lasting calcium $(\mathrm{Ca} 2+)$-plateau of elevated intracellular $\mathrm{Ca}$ levels and altered $\mathrm{Ca}^{2+}$ homeostatic mechanisms in hippocampal neurons surviving brain injury. Eur. J. Neurosci. 2008, 27, 1659-1672.

151. Hell, J.W.; Westenbroek, R.E.; Warner, C.; Ahlijanian, M.K.; Prystay, W.; Gilbert, M.M.; Snutch, T.P.; Catterall, W.A. Identification and differential subcellular localization of the neuronal class C and class D L-type calcium channel alpha 1 subunits. J. Cell. Biol. 1993, 123, 949-962.

152. Hoffmeister, F.; Benz, U.; Heise, A.; Krause, H.P.; Neuser, V. Behavioral effects of nimodipine in animals. Arzneimittel Forschung 1982, 32, 347-360.

153. Lazarewicz, J.W.; Pluta, R.; Puka, M.; Salinska, E. Diverse mechanisms of neuronal protection by nimodipine in experimental rabbit brain ischemia. Stroke 1990, 21, IV108-110.

154. Symon, L.; Harris, R.J.; Branston, N.M. Calcium ions and calcium antagonists in ischaemia. Acta Neurochir. (Wien) 1982, 63, 267-275.

155. Babu, C.S.; Ramanathan, M. Post-ischemic administration of nimodipine following focal cerebral ischemic-reperfusion injury in rats alleviated excitotoxicity, neurobehavioural alterations and partially the bioenergetics. Int. J. Dev. Neurosci. 2011, 29, 93-105.

156. Steen, P.A.; Gisvold, S.E.; Milde, J.H.; Newberg, L.A.; Scheithauer, B.W.; Lanier, W.L.; Michenfelder, J.D. Nimodipine improves outcome when given after complete cerebral ischemia in primates. Anesthesiology 1985, 62, 406-414.

157. Gaab, M.R.; Haubitz, I.; Brawanski, A.; Korn, A.; Czech, T. Acute effects of nimodipine on the cerebral blood flow and intracranial pressure. Neurochirurgia 1985, 28 (Suppl 1), 93-99. 
158. Gelmers, H.J. The effects of nimodipine on the clinical course of patients with acute ischemic stroke. Acta Neurol. Scand. 1984, 69, 232-239.

159. Paci, A.; Ottaviano, P.; Trenta, A.; Iannone, G.; de Santis, L.; Lancia, G.; Moschini, E.; Carosi, M.; Amigoni, S.; Caresia, L. Nimodipine in acute ischemic stroke: A double-blind controlled study. Acta Neurol. Scand. 1989, 80, 282-286.

160. Krieglstein, J.; Lippert, K.; Poch, G. Apparent independent action of nimodipine and glutamate antagonists to protect cultured neurons against glutamate-induced damage. Neuropharmacology 1996, 35, 1737-1742.

161. Maeda, T.; Lee, S.M.; Hovda, D.A. Restoration of cerebral vasoreactivity by an 1-type calcium channel blocker following fluid percussion brain injury. J. Neurotrauma 2005, 22, 763-771.

162. Ercan, M.; Inci, S.; Kilinc, K.; Palaoglu, S.; Aypar, U. Nimodipine attenuates lipid peroxidation during the acute phase of head trauma in rats. Neurosurg. Rev. 2001, 24, 127-130.

163. Bailey, I.; Bell, A.; Gray, J.; Gullan, R.; Heiskanan, O.; Marks, P.V.; Marsh, H.; Mendelow, D.A.; Murray, G.; Ohman, J.; et al. A trial of the effect of nimodipine on outcome after head injury. Acta Neurochir. (Wien.) 1991, 110, 97-105.

164. Teasdale, G.; Bailey, I.; Bell, A.; Gray, J.; Gullan, R.; Heiskanan, O.; Marks, P.V.; Marsh, H.; Mendelow, D.A.; Murray, G.; et al. A randomized trial of nimodipine in severe head injury: Hit I. British/finnish co-operative head injury trial group. J. Neurotrauma 1992, 9, S545-S550.

165. Group, E.S. A multicenter trial of the efficacy of nimodipine on outcome after severe head injury. The european study group on nimodipine in severe head injury. J. Neurosurg. 1994, 80, 797-804.

166. Murray, G.D.; Teasdale, G.M.; Schmitz, H. Nimodipine in traumatic subarachnoid haemorrhage: A re-analysis of the hit I and hit II trials. Acta Neurochir. (Wien.) 1996, 138, 1163-1167.

167. Vergouwen, M.D.; Vermeulen, M.; Roos, Y.B. Effect of nimodipine on outcome in patients with traumatic subarachnoid haemorrhage: A systematic review. Lancet Neurol. 2006, 5, 1029-1032.

168. Aslan, A.; Gurelik, M.; Cemek, M.; Buyukokuroglu, M.; Goksel, H.M.; Eser, O. Nimodipine can diminish oxidative stress in patients with severe head trauma. J. Neurosurg. Sci. 2012, 56, 247-253.

169. Aslan, A.; Gurelik, M.; Cemek, M.; Goksel, H.M.; Buyukokuroglu, M.E. Nimodipine can improve cerebral metabolism and outcome in patients with severe head trauma. Pharm. Res. 2009, 59, 120-124.

170. Langham, J.; Goldfrad, C.; Teasdale, G.; Shaw, D.; Rowan, K. Calcium channel blockers for acute traumatic brain injury. Cochrane Database Syst. Rev. 2003, CD000565.

171. Williams, M.E.; Brust, P.F.; Feldman, D.H.; Patthi, S.; Simerson, S.; Maroufi, A.; McCue, A.F.; Velicelebi, G.; Ellis, S.B.; Harpold, M.M. Structure and functional expression of an omega-conotoxin-sensitive human N-type calcium channel. Science 1992, 257, 389-395.

172. Dubel, S.J.; Starr, T.V.; Hell, J.; Ahlijanian, M.K.; Enyeart, J.J.; Catterall, W.A.; Snutch, T.P. Molecular cloning of the alpha-1 subunit of an omega-conotoxin-sensitive calcium channel. Proc. Natl. Acad. Sci. USA 1992, 89, 5058-5062.

173. Volsen, S.G.; Day, N.C.; McCormack, A.L.; Smith, W.; Craig, P.J.; Beattie, R.; Ince, P.G.; Shaw, P.J.; Ellis, S.B.; Gillespie, A.; et al. The expression of neuronal voltage-dependent calcium channels in human cerebellum. Brain Res. Mol. Brain Res. 1995, 34, 271-282. 
174. Reynolds, I.J.; Wagner, J.A.; Snyder, S.H.; Thayer, S.A.; Olivera, B.M.; Miller, R.J. Brain voltage-sensitive calcium channel subtypes differentiated by omega-conotoxin fraction gvia. Proc. Natl. Acad. Sci. USA 1986, 83, 8804-8807.

175. Hirning, L.D.; Fox, A.P.; McCleskey, E.W.; Olivera, B.M.; Thayer, S.A.; Miller, R.J.; Tsien, R.W. Dominant role of N-type $\mathrm{Ca}^{2+}$ channels in evoked release of norepinephrine from sympathetic neurons. Science 1988, 239, 57-61.

176. Bowersox, S.; Mandema, J.; Tarczy-Hornoch, K.; Miljanich, G.; Luther, R.R. Pharmacokinetics of SNX-111, a selective N-type calcium channel blocker, in rats and cynomolgus monkeys. Drug Metab. Dispos. 1997, 25, 379-383.

177. Bowersox, S.S.; Gadbois, T.; Singh, T.; Pettus, M.; Wang, Y.X.; Luther, R.R. Selective N-type neuronal voltage-sensitive calcium channel blocker, SNX-111, produces spinal antinociception in rat models of acute, persistent and neuropathic pain. J. Pharmacol. Exp. Ther. 1996, 279, 1243-1249.

178. Bowersox, S.S.; Luther, R. Pharmacotherapeutic potential of omega-conotoxin MVIIA (SNX-111), an N-type neuronal calcium channel blocker found in the venom of conus magus. Toxicon 1998, 36, 1651-1658.

179. Berman, R.F.; Verweij, B.H.; Muizelaar, J.P. Neurobehavioral protection by the neuronal calcium channel blocker ziconotide in a model of traumatic diffuse brain injury in rats. J. Neurosurg. 2000, 93, 821-828.

180. Colbourne, F.; Li, H.; Buchan, A.M.; Clemens, J.A. Continuing postischemic neuronal death in CA1: Influence of ischemia duration and cytoprotective doses of NBQX and SNX-111 in rats. Stroke 1999, 30, 662-668.

181. Perez-Pinzon, M.A.; Yenari, M.A.; Sun, G.H.; Kunis, D.M.; Steinberg, G.K. SNX-111, a novel, presynaptic N-type calcium channel antagonist, is neuroprotective against focal cerebral ischemia in rabbits. J. Neurol. Sci. 1997, 153, 25-31.

182. Valentino, K.; Newcomb, R.; Gadbois, T.; Singh, T.; Bowersox, S.; Bitner, S.; Justice, A.; Yamashiro, D.; Hoffman, B.B.; Ciaranello, R.; et al. A selective N-type calcium channel antagonist protects against neuronal loss after global cerebral ischemia. Proc. Natl. Acad. Sci. USA 1993, 90, 7894-7897.

183. Hovda, D.A.; Fu, K.; Badie, H.; Samii, A.; Pinanong, P.; Becker, D.P. Administration of an omega-conopeptide one hour following traumatic brain injury reduces 45 calcium accumulation. Acta Neurochir. Suppl. (Wien.) 1994, 60, 521-523.

184. Samii, A.; Badie, H.; Fu, K.; Luther, R.R.; Hovda, D.A. Effects of an N-type calcium channel antagonist (SNX-111; ziconotide) on calcium-45 accumulation following fluid-percussion injury. J. Neurotrauma 1999, 16, 879-892.

185. Verweij, B.H.; Muizelaar, J.P.; Vinas, F.C.; Peterson, P.L.; Xiong, Y.; Lee, C.P. Improvement in mitochondrial dysfunction as a new surrogate efficiency measure for preclinical trials: Dose-response and time-window profiles for administration of the calcium channel blocker ziconotide in experimental brain injury. J. Neurosurg. 2000, 93, 829-834.

186. Verweij, B.H.; Muizelaar, J.P.; Vinas, F.C.; Peterson, P.L.; Xiong, Y.; Lee, C.P. Mitochondrial dysfunction after experimental and human brain injury and its possible reversal with a selective N-type calcium channel antagonist (SNX-111). Neurol. Res. 1997, 19, 334-339. 
187. Xiong, Y.; Peterson, P.L.; Verweij, B.H.; Vinas, F.C.; Muizelaar, J.P.; Lee, C.P. Mitochondrial dysfunction after experimental traumatic brain injury: Combined efficacy of SNX-111 and U-101033E. J. Neurotrauma 1998, 15, 531-544.

188. Lee, L.L.; Galo, E.; Lyeth, B.G.; Muizelaar, J.P.; Berman, R.F. Neuroprotection in the rat lateral fluid percussion model of traumatic brain injury by SNX-185, an N-type voltage-gated calcium channel blocker. Exp. Neurol. 2004, 190, 70-78.

189. Hinzman, J.M.; Thomas, T.C.; Quintero, J.E.; Gerhardt, G.A.; Lifshitz, J. Disruptions in the regulation of extracellular glutamate by neurons and glia in the rat striatum two days after diffuse brain injury. J. Neurotrauma 2012, 29, 1197-1208.

190. Pruneau, D.; Angus, J.A. Omega-conotoxin GVIA, the N-type calcium channel inhibitor, is sympatholytic but not vagolytic: Consequences for hemodynamics and autonomic reflexes in conscious rabbits. J. Cardiovasc. Pharmacol. 1990, 16, 675-680.

191. Wright, C.E.; Angus, J.A. Prolonged cardiovascular effects of the N-type $\mathrm{Ca}^{2+}$ channel antagonist omega-conotoxin GVIA in conscious rabbits. J. Cardiovasc. Pharmacol. 1997, 30, 392-399.

192. Malmberg, A.B.; Yaksh, T.L. Effect of continuous intrathecal infusion of omega-conopeptides, N-type calcium-channel blockers, on behavior and antinociception in the formalin and hot-plate tests in rats. Pain 1995, 60, 83-90.

193. Penn, R.D.; Paice, J.A. Adverse effects associated with the intrathecal administration of ziconotide. Pain 2000, 85, 291-296.

194. Atanassoff, P.G.; Hartmannsgruber, M.W.; Thrasher, J.; Wermeling, D.; Longton, W.; Gaeta, R.; Singh, T.; Mayo, M.; McGuire, D.; Luther, R.R. Ziconotide, a new N-type calcium channel blocker, administered intrathecally for acute postoperative pain. Reg. Anesth. Pain Med. 2000, 25, 274-278.

195. Staats, P.S.; Yearwood, T.; Charapata, S.G.; Presley, R.W.; Wallace, M.S.; Byas-Smith, M.; Fisher, R.; Bryce, D.A.; Mangieri, E.A.; Luther, R.R.; et al. Intrathecal ziconotide in the treatment of refractory pain in patients with cancer or aids: A randomized controlled trial. JAMA 2004, 291, 63-70.

196. Miljanich, G.P. Ziconotide: Neuronal calcium channel blocker for treating severe chronic pain. Curr. Med. Chem. 2004, 11, 3029-3040.

197. Smith, H.S.; Deer, T.R. Safety and efficacy of intrathecal ziconotide in the management of severe chronic pain. Ther. Clin. Risk Manag. 2009, 5, 521-534.

198. Webster, L.R.; Fisher, R.; Charapata, S.; Wallace, M.S. Long-term intrathecal ziconotide for chronic pain: An open-label study. J. Pain Symptom Manage. 2009, 37, 363-372.

199. Wheaton, P.; Mathias, J.L.; Vink, R. Impact of pharmacological treatments on outcome in adult rodents after traumatic brain injury: A meta-analysis. J. Psychopharm. 2011, 25, 1581-1599.

200. Ishiguro, M.; Wellman, T.L.; Honda, A.; Russell, S.R.; Tranmer, B.I.; Wellman, G.C. Emergence of a R-type $\mathrm{Ca}^{2+}$ channel (Cav 2.3) contributes to cerebral artery constriction after subarachnoid hemorrhage. Circ. Res. 2005, 96, 419-426.

201. Wang, F.; Yin, Y.H.; Jia, F.; Jiang, J.Y. Antagonism of r-type calcium channels significantly improves cerebral blood flow after subarachnoid hemorrhage in rats. J. Neurotrauma 2010, 27, $1723-1732$. 
202. Hansen, P.B. Functional and pharmacological consequences of the distribution of voltage-gated calcium channels in the renal blood vessels. Acta Physiol. 2013, 207, 690-699.

203. Hansen, P.B.; Jensen, B.L.; Andreasen, D.; Friis, U.G.; Skott, O. Vascular smooth muscle cells express the alpha(1a) subunit of a P-/Q-type voltage-dependent $\mathrm{Ca}(2+)$ channel, and it is functionally important in renal afferent arterioles. Circ. Res. 2000, 87, 896-902.

204. Hansen, P.B.; Poulsen, C.B.; Walter, S.; Marcussen, N.; Cribbs, L.L.; Skott, O.; Jensen, B.L. Functional importance of L- and P/Q-type voltage-gated calcium channels in human renal vasculature. Hypertension 2011, 58, 464-470.

205. Canova, D.; Roatta, S.; Micieli, G.; Bosone, D. Cerebral oxygenation and haemodynamic effects induced by nimodipine in healthy subjects. Funct. Neurol. 2012, 27, 169-176.

(C) 2013 by the authors; licensee MDPI, Basel, Switzerland. This article is an open access article distributed under the terms and conditions of the Creative Commons Attribution license (http://creativecommons.org/licenses/by/3.0/). 